\title{
Measuring a Crowdfunding Intention during Covid-19 Pandemic using Planned Behavior Approach
}

\author{
Purnama Putra $^{1 *}$, Tjiptohadi Sawarjuwono ${ }^{2}$, Mas Deden Tirtajaya ${ }^{3}$ \\ \{purnama.p41@gmail.com ${ }^{1}$ \} \\ Islamic Banking, Universitas Islam 45, Indonesia ${ }^{1,3}$ \\ Accounting, Universitas Airlangga, Indonesia ${ }^{2}$
}

\begin{abstract}
Since March to early October 2020 covid-19 (Corona Virus Disease) has caused global outbreaks by infecting 33,842,281 people and 1,010,634 deaths. Covid-19 has become a pandemic that has resulted in casualties and has had a multi-dimensional impact, even though, there are crowdfunding movements as a form of social care. This study aims to analyze what factors influence people's intention in crowdfunding movement for solidarity in pandemic era using Planned Behavior Theory Data were obtained from 250 respondents who were samples of DKI Jakarta residents by purposive sampling using Google form and then processed using SPSS software with multiple regression models. The results of data processing show that the factors based on Planned Behavior, namely: attitudes, subjective norms and perceptions of behavior control simultaneously have a significant positive effect on the increasing intention of the Bekasi city community in the crowdfunding movement. The results of this study are expected to be able to encourage the government and social institutions to optimize the factors that encourage people's intention to do crowdfunding as a form of solidarity with better management, not only incidental movement.
\end{abstract}

Keywords: Crowdfunding, pandemic, intention, behavior

\section{Introduction}

The development of the covid 19 case until October 2020 has made Indonesia the highest country in Asean whose citizens have been confirmed positive. DKI Jakarta is still the province that has the most reported cases of covid 19 but by being able to reduce the Fatality rate to $2.1 \%$, East Java Province which ranks second has a higher and even the highest mortality rate, which is $7.2 \%$. Central Java has 29,395 patients exposed to covid 19, but with the second Fatality rate after East Java, which is $5.4 \%$ [1].

Covid-19 has become a pandemic that has resulted in casualties and has had a multidimensional impact, even though, there are crowdfunding movements as a form of social care. In the broadest sense, solidarity refers to the unification or agreement of feelings or actions, particularly among individuals who share a common interest; or mutual support within a group [2][3]. The moment of the Covid 19 pandemic opened the eyes of both individuals and groups in solidarity because this disaster was experienced by all parties. The feeling of unity, creates action to support each other in order to survive this disaster.

Indonesia's potential in terms of crowdfunding is proven by the awarding of the most generous country award, the World Happiness Report 2019 published by the United Nations (UN) and can be seen from some data that over the past 5 years they have been able to optimize 
online fundraising. The trend of donations has increased significantly as collected by Kitabisa, Rumah Zakat, and Dompet Dhuafa has increased fourfold since March 2020. This rapid increase can be seen after the introduction of online fundraising technology. Kitabisa.com noted that $63 \%$ of people donated via mobile phones, more than 13 thousand donations came from Instagram, and more than $11 \%$ of people donated using go-pay [4][5].

Previous research has been conducted regarding the community's motivation in implementing crowdfunding [6]-[8], the use of the Crowdfunding Platform in fundraising [9][11]. This study seeks to make a difference with the use of Planning Behavior Theory in measuring people's intentions to channel solidarity through crowdfunding platforms during a pandemic. In addition to being a differentiator from other research related to the application of fundraising through a crowdfunding platform, the use of Planned Behavior Theory is expected to be able to prove the generosity of the Indonesian population and increase the research portfolio related to factors that cause people to still care about others even in difficult times.

We have previously researched the community's intention to do good deeds [12]-[16]. This research is expected to be able to provide direction on what factors are most dominant in influencing people's intentions in crowdfunding and optimizing other factors so as to increase fundraising. Hopefully with the Covid 19 pandemic, the community will get blessings with increased awareness and solidarity with others so that people can play an active role in the progress of the nation.

\section{Method}

This is a type of quantitative research; quantitative research can be defined as a research strategy that instills competence in data collection and analysis through the use of a deductive approach to the relationship between theory and research (testing of theory) [17]. This research uses a quantitative paradigm because it uses measurements of the variables to be studied in the form of numbers and to find out what form the relationship is. Sampling was conducted in this study using a non-probability sampling technique combined with a purposive sampling technique. Samples were drawn from those who make charitable contributions and are residents of Jakarta. Jakarta was chosen as the research location due to the diversity of its inhabitants and its status as Indonesia's capital city. The city of Jakarta is divided into five sections: North Jakarta, South Jakarta, West Jakarta, East Jakarta, and Central Jakarta. The 250 respondents in this study were divided into 50 groups of 50 in each of these categories.

This research uses primary data sources that are obtained directly from respondents through closed questionnaires. In this study, the dependent variable is the intention to conduct crowdfunding, denoted by the letter Y. In this study, the independent variables are attitudes, subjective norms, and perceptions of behavioral control, all of which are denoted by the letter $X$. The following equation describes these variables: $a+b_{1} X_{1}+b_{2} X_{2}+b_{3} X_{3} Y=a+b_{1} X_{1}+$ $b_{2} X_{2}+b_{3} X_{3}$. The research instrument consisted of 4 items related to intentions, 9 statements related to attitudes, 7 statements related to subjective norms and 7 statements related to behavioral control perceptions, where each item had been prepared with alternative answers and a weighted value had been determined for each answer.

By utilizing a Likert scale, the instrument is intended to generate accurate data. The Likert scale is used to assess a person's or group's attitudes, opinions, and perceptions toward a social phenomenon [18]. The Likert scale used in this study is a modified version of the standard Likert scale, with four alternative responses, namely (strongly agree, agree, disagree, and strongly 
disagree). The Likert scale with four alternative answers is felt to be the right thing compared to using a Likert scale [19]. Five answers which add up to the neutral answer. In reality in the field, using five alternative answers will make it less accurate to draw conclusions and research results, because it is difficult to provide assessment criteria for neutral answers.

The method of data analysis used in this study consists of three predictors and multiple linear regression analysis. The researchers used multiple regression analysis with three predictors to determine the relationship between attitudes, subjective norms, and perceptions of behavioral control, as well as the community's intention to conduct crowdfunding during the covid 19 pandemic.

\section{Result and Discussion}

Based on data obtained from 250 samples but what can be processed further is 235 . The data discarded came from 15 respondents because they did not fill in completely for the questions given in the questionnaire. The data will be partially and simultaneously tested using SPSS 22 in order to determine the relationship between the dependent variable (intention) and the independent (attitude, subjective norms and perceptions of behavioral control). Before distributing further research instruments, the researcher conducted two tests on these instruments, namely the validity and reliability tests. Based on testing the validity and reliability of the research instrument using Pearson Correlation and Cronbach Alpha to the instrument consist of 4 items of statements related to intention, 9 statements related to attitudes, 7 statements related to subjective norms and 7 statements related to behavioral control perceptions, it resulted in a valid research instrument with a value of $r \geq 0.3$ and reliable with Cronbach Alpha value $\geq 0.70$ [20]. The model in this study is a multiple linear regression model, so before carrying out multiple regression analysis, a classical assumption test is required. If it meets conventional assumptions, linear regression model is called a good model. The classical assumption test is therefore required before the regression analysis is performed. The classical test consists of normality testing, heteroscedastic testing, multicollinearity testing, linearity testing and autocorrelation testing [19],[20]. The normality test was performed with the Kolmogorov-Smirnov. The result was a Sig value of 0.000 and the data received was declared normal because the sig value was $<0.05$. As for the multicollinearity test is used provided that the value of the VIF is not more than 10 , and the tolerance value not less than 0.1 . Table 1 shows the results of the multicollinearity test.

Table 1. Multicollinearity Test

\begin{tabular}{lccc}
\hline \multirow{2}{*}{ Model } & \multicolumn{2}{c}{ Collinearity Statistic } \\
\cline { 2 - 4 } & \multicolumn{3}{c}{ Tolerance } \\
\hline Constant & .905 & & VIF \\
Attitude & .934 & & 1.105 \\
Subjective Norms & .967 & 1.071 \\
Behavioral Control & \multicolumn{2}{c}{} \\
\hline
\end{tabular}

\subsection{Chi-Square goodness of fit test}

The $\mathrm{F}$ test shows the relation between the independent variables and the dependent variable. The "F" test then examines whether the independent variables, namely Attitude (X1), Subjective 
Norms (X2) and Behavioral Control perceptions, have an impact on the dependent variable together, namely the intention of conducting crowdfunding during the covid 19 pandemic (Y). With the $95 \%$ confidence, $\alpha=5 \%$, with the degree of freedom, df (n-k-1). [19], [20]. [20]. Table 2 shows the results of the $\mathrm{F}$ test.:

Table 2. Goodness of Fit Test

\begin{tabular}{|c|c|c|c|c|c|}
\hline Model & Sum of Squares & Df & $\begin{array}{c}\text { Mean } \\
\text { Square }\end{array}$ & $\mathbf{F}$ & Sig. \\
\hline Regression & 79.565 & 3 & 26.522 & 17.430 & $.000^{\mathrm{b}}$ \\
\hline Residual & 194.768 & 232 & 1.522 & & \\
\hline Total & 274.333 & 235 & & & \\
\hline
\end{tabular}

The $\mathrm{F}$ value is calculated $(17,430)$, the $\mathrm{F}$ table is $(2.68)$. F count $(17,430)>\mathrm{F}$ table $(2,67)$ of equal size probability $(0,000)$. Meaning value $=(0.000)<(0.05)$ for a rejection of $\mathrm{H} 0$, the alternative $\mathrm{H}$, which means the model is feasible and has a considerable positive effect between the independent variable and the dependent variable.

\subsection{Partial T-Test}

The $t$ test is used to test if each independent variable, namely Attitude (X1), Subjective Norms (X2), Behavioral Control (X3) and the variable's intention to conduct crowdfunding during the COVID 19 Pandemic, has a positive and significant influence (Y). Each variable is independent of the dependent variable, if one of the independent variables is fixed/controlled) with a probable level of 0,05 and free df (nk-1) [19][20]. Table 3 shows the following partial $t$ test.

Table 3. Partial T-Test

\begin{tabular}{lll}
\hline Model & T value & Sig \\
\hline (Constant) & 1.109 & .269 \\
X1 Attitude & 5.405 & .000 \\
X2 Subjective Norms & 2.735 & .007 \\
X3 Behavioral Control & 1.069 & .287 \\
\hline
\end{tabular}

The following results are obtained on the basis of Table 3: The attitude variable affects the purpose that is demonstrated by the t-value (5.405) $>\mathrm{t}$ table (1.656) and the meaning of the attitude variable is $(0.00)<(0.05)$. $\mathrm{H} 1$ is accepted. And $\mathrm{H} 1$ is accept. Subject standard variables have a positive and significant effect with a value of (2735) > t table (1.656) with a meaning level of $(0.007)<(0.05)$. The variable of the perceptual behavior control has a positive but insignificant $t$-value effect $(1.069)<\mathrm{t}$ table $(1.656)$ and the meaning level is $(0.287)<(0.05)$.

\subsection{Discussion}

\subsubsection{The effect of attitude on intention}

The results of this t test show t to be higher than the t table and that the importance level for the variable attitude is less than 0.05 so that the hypothesis $1(\mathrm{H} 1)$ is acceptable. The results of this study support previous researchers' research [13]-[15],[21]. From the results of this data 
processing, we can see that the attitude of the people of DKI Jakarta greatly influenced their intention to carry out crowdfunding during the COVID-19 pandemic, this was because the more positive public confidence in crowdfunding, the higher the intention to mobilize empathy and solidarity in conducting crowdfunding. For initiators and managers of crowdfunding funds, it is hoped that they will be able to maintain public trust by providing transparency and targeted allocations to maintain and even improve the attitude of the community in carrying out crowdfunding. The more people involved, the better and the greater the positive impact that will be generated.

\subsubsection{The effect of subjective norms on the intention of crowdfunding}

Based on the researchers' data processing results presented in Table 3. It is known that the $t$ test results show that $t$ is greater than $t$ table and the significance level for the subjective norm variable is less than 0.05 , so that hypothesis $2(\mathrm{H} 2)$ is accepted. means that subjective norms have a positive and significant effect on the intention to do crowdfunding.

The results of this data processing do not correspond to the results of research conducted by Putra [14] which indicates that the subjective norm variable has a positive yet minor effect on the intention variable. However, other research results, such as the research results, confirm the positive and significant influence of subjective standards on the intensive choice of Baitul Maal Wat Tamwil (BMT) [12]. And it is supported by research results, which show that subjective standards have a positive and significant effect on the entrepreneurship of students in the Faculty of Economics. [21] The results of data processing can be seen as having a significant positive impact on the intention of people to crowdfund through the selection of a positive direction, which means that believers standards have been raised by the numerous suggestions made by parties such as family, working friends, relatives and religious leaders.

Religious leaders play a role in the formation of individual, family and community norms [22], therefore religious leaders are expected to be stronger in directing solidarity and empathy for others both individually and institutionally so that they are able to withstand all the negative impacts of the COVID19 pandemic.

\subsubsection{The effect of perceptions of behavioral control on the intention of crowdfunding during the covid 19 pandemic}

On the basis of Table 3 it is known that t-test results show that the t-table is higher than Tcount and that its significance is higher than 0.05 , which means it is not significant, and that the hypothesis 3 (H3) is rejected, which means that the perception is not significant. Control of the behavior has a positive but negligible effect on the intention of people to make crowdfunds during the COVID19 pandemic. The results of this data processing are consistent with previous investigations which state that the perception of behavior control does not have a significant impact on Baitul Maal Wat Tamwil's intention [12]. Behavioral control perceptions are feelings of how easy or difficult a person can manifest a behavior influenced by two factors, namely control of beliefs and perceived power [21].

So, it is very important to maintain public trust in crowdfunding fund management. People's beliefs are inherent in their perceptions of life. However, the people of DKI Jakarta prove that even though there are leaks in the management of funds from the community, especially government-managed funds, they are still moving to care for others using the crowdfunding platform. This is proof of the generosity of the Indonesian people, especially the residents of 
Jakarta, to continue crowdfunding even though they are both experiencing difficulties caused by the covid 19 pandemic.

\subsubsection{The influence of attitudes, subjective norms and perceptions of collective behavioral control on the intention of conducting crowdfunding during the covid 19 pandemic}

The feasibility of the multiple regression model in Table 2 results that indicate that the calculated $\mathrm{F}$ value is greater than the $\mathrm{F}$ table, which is positive and significant, thus allowing the acceptance of Hypothesis 4 (H4), which means that the model is practicable and has a significant positive effect between indigenous variables with dependent variabilities. This shows that the variable attitude, subjective norms and behavior management have a substantial positive effect on the intention variable at the same time.

These results are supported by results from previous studies on the "Analysis of Factors affecting the intent of Muzakki to pay Zakat," and it can be seen from multiple regression analyses that together the attitude, subjective standards and perceived behavioral control variables have important effect on the intention variable of paying zakat muzaki [13], [14].

Similarly, previous studies on "Application of theory Of Planned Competence to Generate Entrepreneurial Intentions for Unpaz and Dili Timor Leste" have shown that attitude, subjective standards and perceived behavioral control together have an important influence in encouraging the entrepreneurial intention or intention of economics students [21].

The results of researchers' data processing show that attitudes, subjective norms and the perception of people's behavior control are positive and significant to their intention to finance the crowd, shows that a positive attitude of confidence, the incentive of the people around and control of community behavior will increase people's intention to conduct

The findings of this research have answered the problem or the problem formula in this study, which explains how the perception of behavior management in these studies has no significant and positive effects on the intent of crowdfunding during the Covid 19 pandemic. At the same time, the results of the research show that attitudes, subjective standards and perceptions of behavior management together have a positive and significant effect on the intention to fund the crowd during the covid 19 pandemic.

\section{Conclusion}

This study, which shows that subjective attitudes and norms have a positive and substantial effect on the intention to conduct crowdfunding during the COVID19 pandemic, did not have a significant impact but only positive effect in perception that control of behavior in that research. At the same time, the results of this study show that attitudes, subjective standards and perceptions of behavior control together have a positive and significant impact on the intention to fund the crowd during COVID19.

Based on this research, it is also recommended that the importance of shaping public attitudes, especially regarding public trust in crowdfunding fund management, involving religious leaders and community leaders, and also necessary to carry out social marketing to increase public awareness in transmitting goodness in order to form a strong nation. 


\section{Acknowledgments}

Thank you to the respondents who filled out the questionnaire and students who helped to mobilize questionnaires in several communities regarding data collection on factors that influenced people's intention to crowdfunding during the covid 19 pandemic.

\section{References}

[1] Covid Kemkes, "Situasi Terkini," Situasi-Infeksi-Emerging, https://covid19.kemkes.go.id/situasi-infeksi-emerging/info-corona-virus/situasi-terkiniperkembangan-coronavirus-disease-covid-19-02-oktober-2020/\#.X3w0VGgzY2w.

[2] M. Arab-zozani and S. Hassanipour, "Sharing Solidarity Experiences to Overcome COVID-19," Ann. Glob. Heal., vol. 86, no. 1, p. 114, 2020.

[3] P. Putra and A. Finarti, "Implementasi Maqashid Al- Syari 'ah Terhadap Pelaksanaan CSR Bank Islam: Studi Kasus Pada korporasi, yang kemudian menjadi sangat bermanfaat untuk meningkatkan," Share, vol. 4, no. 1, pp. 37-66, 2015.

[4] A. Evandio, "Donasi Digital Meningkat Selama Pandemi Covid-19," Bisnis.com, 2020 https://finansial.bisnis.com/read/20200519/563/1242695/donasi-digital-meningkat-selamapandemi-covid-19.

[5] D. Warapsari, "Crowdfunding sebagai Bentuk Budaya Partisipatif pada Era Konvergensi Media: Kampanye \# BersamaLawanCorona (Kitabisa. com) Crowdfunding as A Form of Participatory Culture in Media Convergence Era: Kemunculan teknologi digital dan internet memungkinkan," Avant Garde, vol. 08, no. 01, pp. 1-19, 2020.

[6] I. A. Aziz, Nurwahidin, and I. Chailis, "Faktor-Faktor Yang Mempengaruhi Masyarakat Menyalurkan Donasimelalui Platform Crowdfunding Berbasis Online,” Syarikah, vol. 5, no. 1, pp. 94-108, 2019.

[7] K. Choy and D. Schlagwein, "Crowdsourcing for a Better World: On the Relation Between IT Affordances and Donor Motivations in Charitable Crowdfunding," Inf. Technol. \&amp People, vol. 29, no. 1, pp. 221-247, 2016, doi: 10.1108/ITP-09-2014-0215.

[8] R. Gleasure and J. Feller, "A Rift in the Ground: Theorizing the Evolution of Anchor Values in Crowdfunding Communities through the Oculus Rift Case Study,” J. Assoc. Inf. Syst., vol. 17, no. 10, Jan. 2016, doi: 10.17705/1jais.00439.

[9] N. Hutami and Irwansyah, "Pemanfaatan Aplikasi Mobile Kitabisa Dalam Pelaksanaan Crowdfunding Di Indonesia,” J. Komun., vol. 13, no. 2, pp. 183-194, 2019.

[10] F. Abdillah and E. Danial, "Crowdfunding: Demokratisasi Akses Keuangan dalam Mendukung Aksi Sosial Mahasiswa," J. Mimb. Demokr., vol. 15, no. 1, pp. 1-16, 2015.

[11] S. R. Arifin and Wisudanto, "Crowdfunding Sebagai Alternatif Pembiayaan Pembangunan Infrastruktur," 2017.

[12] N. Huda, N. Rini, D. Anggraini, P. Putra, and Y. Mardoni, "Pengaruh Sikap, Norma Subjektif Dan Kendali Prilaku Terhadap Intensi,” J. Manaj., vol. 1, no. 2, pp. 60-74, 2014.

[13] N. Huda, N. Rini, Y. Mardoni, and P. Putra, "The Analysis of Attitudes, Subjective Norms, and Behavioral Control on Muzakki's Intention to Pay Zakah,” Int. J. Bus. Soc. Sci., vol. 3, no. 22, pp. 271-279, 2012.

[14] P. Putra, "Analisis Faktor-Faktor yang Mempengarugi Intensi Muzaki Membayar Zakat: Sebuah Survey pada Masyarakat Kota Bekasi,” Maslahah, vol. 7, no. 1, pp. 99-109, 2016.

[15] P. Putra and Isfandayani, "Planned Behavior Theory in Paying Cash Waqf," Int. J. Psychosoc. Rehabil., vol. 24, no. 04, pp. 5669-5677, 2020, doi: 10.37200/IJPR/V24I4/PR201662.

[16] I. Bukhari, Shahih Bukhari, Juz III. Semarang: Thaha Putra, 1981.

[17] S. Siregar, Metode Penelitian Kuantitatif: Dilengkapi Perbandingan Perhitungan Manual Dan SPSS. Jakarta: Prenadamedia Group, 2015. 
[18] Sugiyono, Statistika untuk Penelitian. Bandung: Afabeta, 2010.

[19] H. Sarjono and W. Julianti, SPSS Vs Lisrell. Jakarta: Salemba Empat, 2011.

[20] Sugiyono, Metode Penelitian Pendidikan Pendekatan Kuantitatif, Kualitatif, dan R \& D. Bandung: Afabeta, 2014.

[21] K. Yasa, S. Suprapti, and L. da Cruz, "Aplikasi Theory of Planned Behavior dalam Membangkitkan Niat Berwirausaha Bagi Mahasiswa Fakultas Ekonomi Unpaz, Dili Timor Leste," E-Jurnal Ekon. dan Bisnis Univ. Udayana, vol. 04, no. 12, pp. 895-920, 2015.

[22] P. Putra and T. Sawarjuwono, "Traditional Market Merchant Attitudes in the Perspective of Islamic Business Ethics,” Opción, vol. 35, no. 20, pp. 1471-1487, 2019, [Online]. Available: https://produccioncientificaluz.org/index.php/opcion/article/view/24594/25041. 